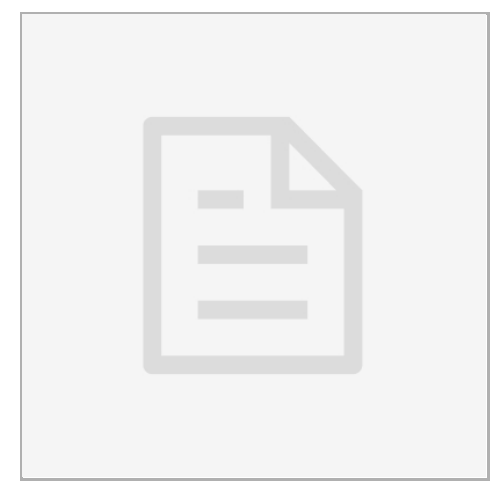

SEP 03, 2020

\section{open ठACCEss}

DOI:

dx.doi.org/10.17504/protocol s.io.bks2 kwge

Protocol Citation: Angel A Justiz-Vaillant, Belkis FerrerCosme 2020. ELISA for quantification of Granulocytecolony stimulator factor (GCSF) in human serum or plasma. protocols.io https://dx.doi.org/10.17504/p rotocols.io.bks $2 \mathrm{kwge}$

License: This is an open access protocol distributed under the terms of the Creative Commons Attribution License, which permits unrestricted use, distribution, and reproduction in any medium, provided the original author and source are credited

\section{Protocol status: In} development We are still developing and optimizing this protocol

Created: Sep 03, 2020

Last Modified: Sep 03, 2020

PROTOCOL integer ID:

41530

\title{
(3) ELISA for quantification of Granulocyte-colony stimulator factor (G-CSF) in human serum or plasma
}

\author{
Angel A Justiz-Vaillant ${ }^{1}$, Belkis Ferrer-Cosme ${ }^{2}$ \\ ${ }^{1}$ University of the West Indies St. Augustine; \\ 2"Saturnino Lora Torres" Provincial Teaching Clinical Surgical Hospital. \\ Cuba
}

University of the West Indies

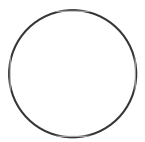

Angel A Justiz-Vaillant

University of the West Indies St. Augustine

\section{DISCLAIMER - FOR INFORMATIONAL PURPOSES ONLY; USE AT YOUR OWN RISK}

The protocol content here is for informational purposes only and does not constitute legal, medical, clinical, or safety advice, or otherwise; content added to protocols.io is not peer reviewed and may not have undergone a formal approval of any kind. Information presented in this protocol should not substitute for independent professional judgment, advice, diagnosis, or treatment. Any action you take or refrain from taking using or relying upon the information presented here is strictly at your own risk. You agree that neither the Company nor any of the authors, contributors, administrators, or anyone else associated with protocols.io, can be held responsible for your use of the information contained in or linked to this protocol or any of our Sites/Apps and Services.

1 An anti-human granulocyte-colony stimulator factor (G-CSF) coating antibody is adsorbed onto the microwells by incubation overnight at $4^{\circ} \mathrm{C}$ with carbonate-bicarbonate buffer. 
2 Add $50 \mu$ l of human serum. Human G-CSF present in the serum sample binds to antibodies adsorbed into the microwells.

3 The microplate is blocked with $3 \%$ non-fat milk-PBS buffer and later wash to remove unbound proteins.

4 Fifty (50) $\mu \mathrm{l}$ of biotin-conjugated anti-G-CSF antibody is added. The optimal dilution must be investigated.

5 The microplate is rewashed with PBS-Tween 20 buffer, $\mathrm{pH} 7.4$.

6 One hundred $\mu$ l of streptavidin-HRP conjugate is added and it binds to the biotin-conjugated antihuman G-CSF antibody.

7 The plate is washed following incubation to remove the unbound Streptavidin-HRP.

8 Add $100 \mu$ l of 3,3',5,5'- tetramethylbenzidine (TMB; Sigma-Aldrich) into each well.

9 Incubate the microwells in the dark for $15 \mathrm{~min}$. 
10 A colored product is formed in proportion to the quantity of G-CSF present in the sample or standard.

11 The reaction is terminated by addition of $100 \mu \mathrm{l} 3 \mathrm{M} \mathrm{H} 2 \mathrm{SO} 4$ and the absorbance is measured at $450 \mathrm{~nm}$.

12 A standard curve is made from 7 human G-CSF standard dilutions and the human G-CSF sample concentration is determined.

13 For better results place the microplate on a microplate shaker in every incubation. 